\title{
Control of Apple Scab and Cytospora Canker with Paclobutrazol
}

\author{
Gary Watson and Karel Jacobs
}

\begin{abstract}
Forty Malus 'Radiant' crabapples, a variety known to be highly susceptible to apple scab disease, were field-planted then treated three months later with paclobutrazol (PBZ) as a basal drench, at rates of $0,0.8,1.6$, and $2.4 \mathrm{~g}$ a.i./cm caliper. Apple scab was significantly reduced for two years post treatment by all rates of PBZ applied. However, significant growth regulation occurred through the third and final year of the study. Thirty Picea pungens (Colorado spruce) trees in containers were treated with PBZ, applied as a basal drench, at rates of $0,1.6$, and $3.2 \mathrm{~g}$ a.i./cm caliper. Cytospora canker development from subsequent branch inoculations was significantly reduced by both PBZ treatment rates and persisted through the end of the two year monitoring period. Cytospora canker disease control with only moderate growth regulation indicates that a PBZ basal drench could be developed into a viable landscape treatment.

Key Words. Colorado Spruce; Crabapple; Disease Control; Growth Regulation; Paclobutrazol; Picea pungens.
\end{abstract}

Paclobutrazol (PBZ) is a triazole-based compound with noted plant growth regulator activity. PBZ inhibits biosynthesis of gibberellins in plants, and sterols in fungi, by blocking steps in the isoprenoid pathway (Rademacher 2000). Gibberellins are plant growth hormones that mediate stem elongation and leaf size. Plants treated with PBZ develop a shorter, more compact form with reduced length between internodes as well as smaller leaves (Davis et al. 1985). The growth-regulating attributes have resulted in PBZ being used in utility arboriculture to extend line clearance trim cycles and reduce outages (Mann et al. 1995; Burch et al. 1996; Asín et al. 2007). Sterols are required for fungal cell membrane function (Baldwin and Rathmell 1988). Sterol inhibition is the mode of action of closely related triazole fungicides.

Root systems of trees treated with PBZ can have increased extension (Watson 2004) and greater fine root density (Watson 1996). PBZ has been shown to improve cold, flood, and salt tolerance in several plant taxa (Lin et al. 2006a; Lin et al. 2006b; Hajihashemi et al. 2007). Higher plant water potential (Ashokan et al. 1995; Watson 2001), and reduced stomatal conductance (Ashokan et al. 1995) and water use (Wample and Culver 1983; Ruter and Martin 1994) have also been documented. These combined effects of PBZ on reducing plant stress may contribute to reducing the severity of plant diseases. PBZ applied to mature trees as a basal drench produced slight control of bacterial leaf scorch on pin and red oak when the severity of disease prior to treatment was moderate (causal agent Xylella fastidiosa) (Hartman et al. 2010).

PBZ has fungitoxic properties (Jacobs and Berg 2000; Blaedow et al. 2006), owing to its inhibition of fungal sterol biosynthesis (Baldwin and Rathmell 1988), and is effective in controlling some diseases. For example, on mature crabapples, basal drench applications of PBZ suppressed apple scab disease (causal agent Venturia inaequalis), but not when applied to smaller trees at planting (Blaedow et al. 2006; Percival 2008). McDonald et al.
(2006) found that PBZ suppressed dollar spot foliar disease of creeping bentgrass (causal agent Sclerotinia homoeocarpa) but had no effect on gray leaf spot (causal agent Pyricularia grisea).

The intention of this study was to determine if a PBZ soil drench treatment could control two diseases: apple scab (causal agent Venturia inaequalis) and cytospora canker (causal agent teliomorph Leucostoma kunzeii var. piceae; anamorph Cytospora kunzei) when applied to young, susceptible host trees. The PBZ formulation used in this research study is currently not labeled for control of fungal diseases.

\section{METHODS}

\section{Crabapple: Apple Scab}

Forty, $3.0 \mathrm{~cm}$ caliper bare root Malus 'Radiant' crabapples, a variety known to be highly susceptible to apple scab (Beckerman et al. 2009), were purchased (Bailey Nursery, St. Paul, Minnesota, U.S.) and planted on $1.5 \mathrm{~m}$ centers in a research field nursery at The Morton Arboretum (Lisle, Illinois, U.S.) in June 2001. Drip irrigation was provided as needed throughout the study. PBZ (Cambistat 2SC, Rainbow Treecare Scientific Advancements, Minneapolis, Minnesota, U.S.) was applied as a basal drench on September 5,2001 , at rates of $0,0.8,1.6$, and $2.4 \mathrm{~g}$ a.i./cm caliper. The recommended label rate for crabapple is $1.6 \mathrm{~g}$ a.i./ $/ \mathrm{cm}$. The four treatments were applied to trees using a completely randomized design.

Terminal twig growth and leaf area measurements were recorded annually in August beginning in 2002. Terminal twig growth was measured on three vigorous, non-apical branches, from the upper half of the crown. When growth was too small to measure accurately, it was recorded as $1 \mathrm{~cm}$. Four undamaged fully expanded leaves from the same branches were collected to measure leaf area on a Delta-T (video) 
Area Meter. Relative chlorophyll content was measured on four leaves from each tree with a Minolta SPAD-502 meter.

Apple scab symptoms were rated three times each year, from June through mid-August, when premature leaf fall, due to the infection, had begun. Each crabapple was visually rated by two people, and the average disease severity rating (DSR) rating was used. The DSR scale used was: $0(<5 \%$ of leaves in the canopy showing symptoms), $1(5 \%-25 \%), 2(26 \%-50 \%), 3(51 \%-75 \%)$, $4(76 \%-100 \%)$, or 5 (near $100 \%$ and substantial leaf loss).

\section{Colorado Spruce: Cytospora Canker}

Sixty Colorado spruce (Picea pungens) trees in \#7 (22-29 L) containers were purchased (Bailey Nursery, St. Paul, Minnesota, U.S.) in July 2004 and maintained in the containers at The Morton Arboretum throughout the experiment. PBZ was applied as a basal drench on July 24,2004 , at rates of $0,1.6$, and $3.2 \mathrm{~g}$ a.i./cm caliper. The recommended label rate for Colorado spruce is $1.6 \mathrm{~g}$ a.i. $/ \mathrm{cm}$. The three treatments were applied to trees using a randomized complete block design.

In June 2005, half of the 12 trees in each PBZ rate group were inoculated with Leucostona kunzei, the causal agent of cytospora canker disease on blue spruce. The fungus was isolated from infected trees and maintained on potato dextrose agar (PDA) at $25^{\circ} \mathrm{C}$ until inoculation. Inoculation consisted of aseptically collecting a $5 \mathrm{~mm}$ mycelial agar plug and inserting it into a small incision made on the abaxial surface of a $1-2 \mathrm{~cm}$ diameter branch on each tree. A sterile PDA agar plug was inserted into a different branch to act as a non-inoculated control.

Twig elongation measurements were taken in 2005 and 2006 by averaging apical growth of lateral branches from the upper and lower halves of each quadrant (eight total). Growth of the leaders was also measured.

Disease severity was evaluated monthly throughout the growing season in 2005 and 2006 using a DSR scale of 0 to 3: 0 (healthy, no symptoms on branch), 1 (some resin and/or slight browning or purpling of needles around inoculation point), 2 (substantial browning of needles beyond inoculation point, resin still visible and more pronounced), or 3 (branch completely browned).

\section{Statistical Analyses}

Twig growth, leaf area, and SPAD data were compared with one-way ANOVA $(P \leq 0.05)$ with separation of means by the Tukey method (SigmaStat 2.0, SPSS Science, Chicago, Illinois, U.S.). DSR data was analyzed using a generalized mixed model (SAS procedure PROC MIXED, SAS 9.2), and Hochberg-adjusted $P$-values (SAS procedure PROC MULTTEST, SAS 9.2). Significance is reported when $P<0.05$.

\section{RESULTS AND DISCUSSION}

\section{Apple Scab}

Apple scab severity was significantly suppressed for two years by all applied rates of PBZ (Table 1; Figure 1). Disease suppression improved with increasing PBZ rate (Table 1). The DSR data indicated that the disease progression was slowed in both 2002 and 2003 by all rates of PBZ applied. Less than 50\% of the canopies of treated trees were symptomatic in June and July, compared with $75 \%$ to $100 \%$ of the canopies of untreated control trees. Treated trees remained less symptomatic than controls through the final rating in each of the first two years. By the third year, there was no disease suppression by any PBZ treatment.

All rates of PBZ significantly reduced shoot growth and increased SPAD values (greener leaves) for all three years. Leaf surface area was reduced only in the first year. There was no difference in twig growth regulation among the three PBZ rates in any year (Table 2). All of the trees in the $1.6 \mathrm{~g}$ and $2.4 \mathrm{~g}$ treatment groups, and half of the trees in the $0.8 \mathrm{~g}$ treatment group, had twig growth of only about $1 \mathrm{~cm}$ total in three years. This is compared to over $50 \mathrm{~cm}$ of total twig growth in the untreated controls. The growth regulation amounted to a $95 \%$ reduction compared to untreated trees. This greater than anticipated level of regulation may have been due, at least in part, to the use of small trees. The smallest diameter tree the chemical included on the label is $10 \mathrm{~cm} \mathrm{DBH}$.

Two years of apple scab disease suppression was attained on a highly susceptible cultivar of crabapple after one basal drench treatment. However, the PBZ label recommends reapplication every third year to maintain tree growth regulation. If apple scab is only suppressed for two years, there will be a third year with no disease suppression between PBZ treatments. Though scab was reduced when disease pressure was especially high (2002), $75 \%$ of the canopy still exhibited symptoms by August.

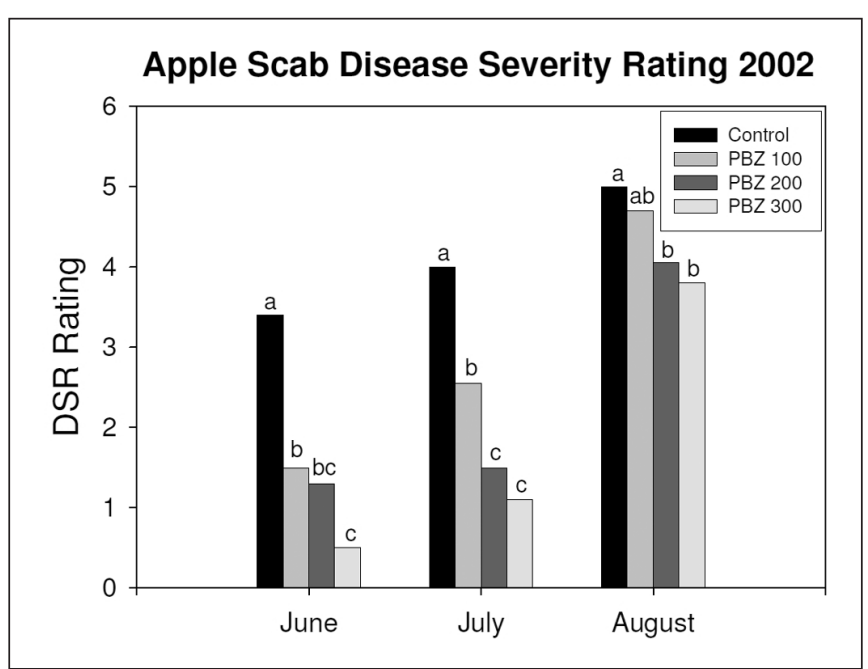

Figure 1. August mean DSR for Malus 'Radiant' trees treated with 3 rates of paclobutrazol or control. Values represent means of 10 trees. Different letters above the bars within each group indicate a significant difference between rates.

Table 1. Monthly mean DSR for Malus 'Radiant' trees treated with three rates of Paclobutrazol or control. Values represent means of 10 trees. Different letters after values across each row (month) indicate a significant difference between rates.

\begin{tabular}{lcccc}
\hline & Control & $0.8 \mathrm{~g} \mathrm{PBZ}$ & $1.6 \mathrm{~g}$ PBZ & $2.4 \mathrm{~g}$ PBZ \\
\hline June 2002 & $3.4 \mathrm{a}$ & $1.5 \mathrm{~b}$ & $1.3 \mathrm{bc}$ & $0.5 \mathrm{c}$ \\
July 2002 & $4.0 \mathrm{a}$ & $2.6 \mathrm{~b}$ & $1.5 \mathrm{c}$ & $1.1 \mathrm{c}$ \\
August 2002 & $5.0 \mathrm{a}$ & $4.7 \mathrm{ab}$ & $4.1 \mathrm{~b}$ & $3.8 \mathrm{~b}$ \\
& & & & \\
June 2003 & $3.5 \mathrm{a}$ & $1.6 \mathrm{~b}$ & $1.1 \mathrm{~b}$ & $0.9 \mathrm{~b}$ \\
July 2003 & $3.7 \mathrm{a}$ & $2.0 \mathrm{~b}$ & $1.4 \mathrm{bc}$ & $1.0 \mathrm{c}$ \\
August 2003 & $3.8 \mathrm{a}$ & $2.8 \mathrm{~b}$ & $2.6 \mathrm{bc}$ & $1.7 \mathrm{c}$ \\
& & & & \\
June 2004 & $4.0 \mathrm{a}$ & $4.0 \mathrm{a}$ & $3.9 \mathrm{a}$ & $3.7 \mathrm{a}$ \\
July 2004 & $4.4 \mathrm{a}$ & $4.2 \mathrm{a}$ & $4.1 \mathrm{a}$ & $4.0 \mathrm{a}$ \\
August 2004 & $4.9 \mathrm{a}$ & $4.6 \mathrm{a}$ & $4.5 \mathrm{a}$ & $4.0 \mathrm{a}$ \\
\hline
\end{tabular}


Table 2. Growth and SPAD measurements of crabapple trees treated with three rates of the growth regulator paclobutrazol.

\begin{tabular}{llll}
\hline Twig Growth $(\mathrm{cm})$ & & & \\
& $2002^{\mathrm{z}}$ & 2003 & 2004 \\
\hline Control & $18.5 \mathrm{a}$ & $21.6 \mathrm{a}$ & $11.4 \mathrm{a}$ \\
$0.8 \mathrm{~g}$ PBZ & $1.0 \mathrm{~b}$ & $1.0 \mathrm{~b}$ & $3.2 \mathrm{~b}$ \\
$1.6 \mathrm{~g} \mathrm{PBZ}$ & $1.1 \mathrm{~b}$ & $1.0 \mathrm{~b}$ & $1.0 \mathrm{~b}$ \\
$2.4 \mathrm{~g}$ PBZ & $1.0 \mathrm{~b}$ & $1.0 \mathrm{~b}$ & $1.2 \mathrm{~b}$ \\
& & & \\
Leaf area $\left(\mathrm{mm}^{2}\right)$ & & & \\
Control & $2,307 \mathrm{a}$ & $1,956 \mathrm{a}$ & $1,844 \mathrm{a}$ \\
$0.8 \mathrm{~g}$ PBZ & $780 \mathrm{~b}$ & $1,880 \mathrm{a}$ & $2,133 \mathrm{a}$ \\
$1.6 \mathrm{~g}$ PBZ & $719 \mathrm{~b}$ & $1,494 \mathrm{a}$ & $1,876 \mathrm{a}$ \\
$2.4 \mathrm{~g}$ PBZ & $691 \mathrm{~b}$ & $1,544 \mathrm{a}$ & $1,974 \mathrm{a}$ \\
& & & \\
Relative chlorophyll content (SPAD) & & \\
Control & $32.7 \mathrm{a}$ & $35.5 \mathrm{a}$ & $34.0 \mathrm{a}$ \\
$0.8 \mathrm{~g}$ PBZ & $48.4 \mathrm{~b}$ & $42.2 \mathrm{~b}$ & $40.0 \mathrm{~b}$ \\
1.6 g PBZ & $49.2 \mathrm{~b}$ & $45.1 \mathrm{~b}$ & $42.3 \mathrm{~b}$ \\
$2.4 \mathrm{~g}$ PBZ & $51.9 \mathrm{~b}$ & $46.3 \mathrm{c}$ & $42.3 \mathrm{~b}$ \\
\hline
\end{tabular}

${ }^{\mathrm{z}}$ Values followed by the same letter in the same column for each type of measurement are not significantly different $(P \leq 0.05)$.

\section{Cyptospora Canker}

None of the 30 control (PDA-only-inoculated) branches developed cytospora canker. Their DSR ratings averaged at most, 0.4 during the two years of the study. A rating greater than zero is due to some branches intermittently showing needle discoloration (hence were given a DSR rating greater than 0) that was not found to be associated with disease progression.

In contrast, disease symptoms rapidly developed within three months on inoculated branches of trees that were not treated with PBZ (Figure 2). Half of the Leucostoma-inoculated branches on the untreated trees died (DSR $=3$ ) early in the second year. The majority of the Leucostoma-inoculated branches on remaining trees in this group developed disease symptoms and were rated 2 (substantial leaf browning and pronounced resin present).

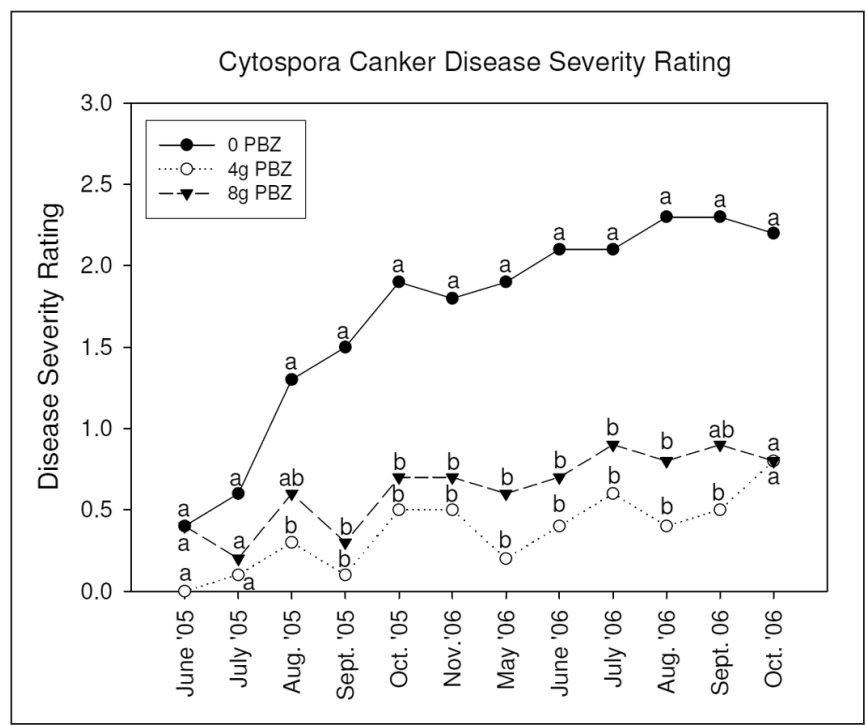

Figure 2. Monthly average DSR for 30 Colorado spruce trees treated with two rates of Paclobutrazol or Control. Values represent means of 10 trees. Within each month, different letters indicate a significant difference between treatments.
PBZ applied at label rate and twice label rate prevented cytospora canker disease development. None of the Leucostomainoculated branches on trees treated with either rate of PBZ died. Approximately half of the inoculated branches showed only minor discoloration or resin on some evaluation dates. Like the uninoculated trees, the discoloration never progressed and the branches were never given a rating higher than 1 .

There was no growth regulation measured in 2005, because PBZ was applied late in the season and after the annual growth was complete. Still, the disease control data indicate that some degree of PBZ was taken up by the roots and transported to the branches in the first season. Growth of the central leader was reduced significantly in the second year, in 2006 (Table 3). Both rates of PBZ reduced leader growth by approximately half. The leader growth regulation was not excessive and only gave the appearance of slower growth. Lateral shoot growth was not reduced by either PBZ treatments for the two years of the study.

Table 3. Growth of Colorado spruce trees for two seasons after July $\mathbf{2 0 0 5}$ mid-summer application of the growth regulator paclobutrazol.

\begin{tabular}{llclr}
\hline $\begin{array}{l}\text { PBZ rate } \\
(\mathrm{g} / \mathrm{cm})\end{array}$ & \multicolumn{2}{l}{ Lateral branch tips } & \multicolumn{2}{l}{ Leader } \\
\hline 0 & $2005^{\mathrm{z}}$ & 2006 & 2005 & 2006 \\
\hline 1.6 & $10.1 \mathrm{a}$ & $4.5 \mathrm{a}$ & $19.7 \mathrm{a}$ & $10.2 \mathrm{a}$ \\
3.2 & $10.0 \mathrm{a}$ & $3.0 \mathrm{a}$ & $19.0 \mathrm{a}$ & $4.5 \mathrm{~b}$ \\
& $9.1 \mathrm{a}$ & $3.1 \mathrm{a}$ & $17.8 \mathrm{a}$ & $4.8 \mathrm{~b}$ \\
\hline
\end{tabular}

${ }^{\mathrm{z}}$ Values followed by the same letter in the same column for each type of measurement are not significantly different $(P \leq 0.05)$.

Leader and lateral growth of untreated control trees was only half as much in 2006 compared to 2005, probably because the trees were becoming pot-bound. The slow growth may have contributed to the lack of growth regulation of lateral branches $(p=$ 0.085 ). The rapid canker development in inoculated and untreated trees may have been enhanced by tree stress caused by the confined root system in the containers. Cytospora canker is a stressrelated disease, especially moisture stress (Sinclair et al. 1987).

To summarize, one soil drench application of PBZ was able to control natural infection of apple scab and artificial infection of cytospora canker for two years in small trees. All rates tested were similarly effective in controlling both diseases. Growth reduction of crabapples was extreme at all rates applied, yet more than $75 \%$ of the canopies of treated crabapples were symptomatic of apple scab by August. This may render the use of PBZ unacceptable for landscape trees. Further study may be warranted. Disease suppression may be better and longer lasting on crabapple varieties somewhat less susceptible apple scab.

Extreme growth regulation was not seen with blue spruce trees in containers at up to twice the label rate. Cytospora canker was controlled with only moderate growth regulation occurring in the second season. This is a promising indication that natural infections of the disease may be able to be controlled by basal application of PBZ without excessive growth regulation. Certainly some control of spruce tree growth can be a desirable objective in small, urban landscapes. There are currently no pesticides labeled to control cytospora canker disease, which is common in urban environments. Additional study of PBZ control on existing cankers, especially on larger trees is needed. 
Acknowledgments. This study was supported, in part, by a grant from Rainbow Treecare Scientific Advancements. The authors wish the thank Angela Hewitt and Kelly Bolger for their assistance and support of this project.

\section{LITERATURE CITED}

Ashokan, P.K., W.R. Chaney, and G.S. Premachandra. 1995. Soil applied paclobutrazol affects leaf water relations and growth of American elm (Ulmus americana L.) seedlings. Plant Growth Regulation Society of America Quarterly 23:1-12.

Asín, L., S. Alegre, and R. Montserrat. 2007. Effect of paclobutrazol, prohexadione-Ca, deficit irrigation, summer pruning and root pruning on shoot growth, yield, and return bloom, in a 'Blanquilla' pear orchard. Scientia Horticulturae 113:142-148.

Baldwin, B.C., and W.G. Rathmell. 1988. Evolution of concepts for chemical control of plant disease. Annual Review of Phytopathology 26:265-283.

Beckerman, J.L., J. Chatfield, and E. Draper. 2009. A 33-year evaluation of resistance and pathogenicity in the apple scab - crabapples pathosystem. HortScience 44:599-608.

Blaedow, R.A., W.R. Chaney, P.C. Pecknold, and H.A. Holt. 2006. Investigation of fungicidal properties of the tree growth regulator paclobutrazol to control apple scab. Arboriculture \& Urban Forestry 32:67-73.

Burch, P.L., R.H. Wells, and W.N. Kline III. 1996. Red maple and silver maple growth evaluated 10 years after application of paclobutrazol tree growth regulator. Journal of Arboriculture 22:61-66.

Davis, T.D., N. Sankhla, R.H. Walser, and A. Upadhyaya. 1985. Promotion of adventitious root formation on cuttings by paclobutrazol. HortScience 20:883-884

Hajihashemi, S., K. Kiarostami, A. Saboora, and S. Enteshari. 2007. Exogenously applied paclobutrazol modulates growth in salt-stressed wheat plants. Plant Growth Regulation 53:117-128.

Hartman, J., E. Dixon, and S. Bernick. 2010. Evaluation of therapeutic treatments to manage oak bacterial leaf scorch. Arboriculture \& Urban Forestry 36:140-146.

Jacobs, K.A., and L.C. Berg. 2000. Inhibition of fungal pathogens of woody plants by the plant growth regulator paclobutrazol. Pest Management Science 56:407-412.

Lin, K.H., F.H. Pai, S.Y Hwang, and H.F. Lo. 2006a. Pre-treating paclobutrazol enhanced chilling tolerance of sweet potato. Plant Growth Regulation 49:249-262.

Lin, K.H., C.C. Tsou, S.Y. Hwang, L.F.O. Chen, and H.F. Lo. 2006 b. Paclobutrazol pre-treatment enhanced flooding tolerance of sweet potato. Journal of Plant Physiology 163:750-760.
McDonald, S.J., P.H. Dernoeden, and C.A. Bigelow. 2006. Dollar spot and gray leaf spot severity as influenced by irrigation, chlorothalonil, paclobutrazol, and a wetting agent. Crop Science 46:2675-2684.

Mann, M.P., H.A. Holt, W.R. Chaney, W.L. Mills, and R.L. McKenzie. 1995. Tree growth regulators reduce line clearance trimming time. Journal of Arboriculture 21:209-212.

Percival, G.C. 2008. Paclobutrazol soil drenches provide partial reductions in symptoms of apple scab of ornamental trees and Guignardia leaf blotch of horse chestnut. Journal of Environmental Horticulture 26(2):87-92.

Rademacher, W. 2000. Growth retardants: Effects on gibberellins biosynthesis and other metabolic pathways. Annual Review of Plant Physiology and Plant Molecular Biology 51:501-531.

Ruter, J.M., and C.A. Martin. 1994. Effects of contrasting climate and paclobutrazol on the growth and water use of two container-grown landscape plants. Journal of Environmental Horticulture 12:27-32.

Sinclair, W.A., H.H. Lyon, and W.T. Johnson. 1987. Diseases of Trees and Shrubs. Comstock Publishing, Cornell University Press, Ithaca, New York, U.S. 575 pp.

Wample, R.L., and E.B. Culver. 1983. The influence of paclobutrazol, a new growth regulator, on sunflowers. Journal of the American Society of Horticulture Science 108:122-125.

Watson, G.W. 1996. Tree root system enhancement with paclobutrazol. Journal of Arboriculture 22:211-217.

Watson, G.W. 2001. Soil applied paclobutrazol affects root growth, shoot growth and water potential of American elm seedlings. Journal of Environmental Horticulture 19:199-122.

Watson, G.W. 2004. Effect of paclobutrazol and transplanting on root growth of green column black maple and summit green ash. Journal of Environmental Horticulture 22:209-212.

Gary Watson (corresponding author)

The Morton Arboretum

4100 Illinois Route 53

Lisle, Illinois 60532, U.S.

gwatson@mortonarb.org

Karel Jacobs

Chicago State University

9100 S. King Drive/SCI310

Chicago, Illinois 60628-3759, U.S. 
Résumé. Quarante Malus 'Radiant', un cultivar de pommetier reconnu pour être hautement susceptible à la tavelure, ont été plantés en champ et par la suite traités trois mois plus tard avec la paclobutrazol (PBZ) par application sur le sol au pied des arbres à des taux de 0, 0,8, 1,6 et 2,4 $\mathrm{g}$ d'ingrédient actif par centimètre de calibre de tronc. La tavelure a été significativement réduite durant deux ans après le traitement avec toutes les concentrations de PBZ employées. Cependant, une régulation significative de la croissance est survenue lors de la troisième et de la dernière année de l'étude. Trente Picea pungens (épinette du Colorado) en pot ont été traitées avec le PBZ par application sur le sol au pied des arbres à des taux de $0,1,6$ et 3,2 $\mathrm{g}$ d'ingrédient actif par centimètre de calibre de tronc. Le développement du chancre cytosporéen à partir d'inoculations subséquentes de la maladie sur des branches a été significativement diminué avec toutes les concentrations de PBZ et cela a persisté jusqu'à la fin des deux années de la période de suivi. Le contrôle du chancre cytosporéen avec seulement une quantité modérée de régulateur de croissance indique qu'une méthode d'application au pied sur le sol de PBZ pourrait être développée en tant que traitement viable en aménagement.

Zusammenfassung. Vierzig Zieräpfel Malus Radiant, eine Varietät, die bekanntermaßen sehr anfällig für die Apfelschorf-Krankheit ist, wurden in Feldversuchen gepflanzt und drei Monate später mit Paclobutrazol (PBZ) als basale Applikation in Raten von 0, 0,8, 1,6 und 2,4 g a.i./cm Stammumfang behandelt. Der Apfelschorf wurde bei allen drei Raten von PBZ signifikant für die nächsten zwei Jahre nach der Behandlung reduziert. Dennoch traten signifikante Wachstumseingriffe im dritten und vierten Jahr der Studie auf. Dreißig Stechfichten (Picea pungens) im Container wurden mit einer basalen Applikation von PBZ zu Raten von 0, 1,6 und 3,2 g a.i./cm Stammumfang behandelt. Die Entwicklung von Cytospora-Krebs aus einer nachfolgenden Inokulation der Äste wurde deutlich durch die PBZ-Gabe reduziert und hielt an bis zum Ende der zweijährigen Beobachtungszeit. Die Kontrolle von Cytospora-Krebs mit nur moderater Wachstumsregulation zeigt, dass eine basale Tränkung mit PBZ in eine nützliche Behandlungspraxis im Landschaftsbau einfließen kann.

Resumen. Cuarenta manzanos 'Radiant', una variedad conocida por ser altamente susceptible a la enfermedad de la costra del manzano, fueron plantados en el campo y tratados tres meses más tarde con paclobutrazol (PBZ), con una zanja basal, a tasas de $0,0.8,1.6$, y $2.4 \mathrm{~g}$ a.i./ $\mathrm{cm}$ de calibre. La costra del manzano fue significativamente reducida por dos años después del tratamiento para todas las tasas de PBZ aplicadas. Sin embargo, ocurrió regulación significativa del crecimiento a través del tercer y final año del estudio. Treinta árboles de Picea pungens (Colorado spruce) en contenedores fueron tratados con PBZ, aplicado como una zanja basal, a tasas de $0,1.6$, and $3.2 \mathrm{~g}$ a.i./.cm de calibre. El desarrollo del cancro citósforora de las subsecuentes inoculaciones en las ramas fue reducido significativamente para ambos tratamientos con PBZ y persistió a través del final de los dos años del periodo de monitoreo. El control de la enfermedad del cancro citósforora, con solamente una moderada regulación del crecimiento, indica que una zanja basal de PBZ podría ser desarrollada como un tratamiento viable en paisajes urbanos. 